\title{
The Benefactive Construction in South Efate
}

\author{
Nick Thieberger
}

UNIVERSITY OF MELBOURNE

\begin{abstract}
The benefactive construction in South Efate employs a prepositional phrase in the position immediately preceding the main verb. This position facilitates the expression of an additional participant in a sentence without competing for slots held by other participants (core arguments or adjuncts). Possessive morphology encoding the benefactive has been noted for other Oceanic languages, with distinct word-order marking a final stage of grammaticalization of the benefactive. While South Efate shares features with southern Vanuatu languages, it is shown that a preverbal benefactive is an areal feature of several languages to the north of South Efate, potentially supporting South Efate's position in the Central Vanuatu subgroup.
\end{abstract}

1. INTRODUCTION. ${ }^{1}$ South Efate is an Oceanic language spoken in central Vanuatu. It has SVO word order, and distinguishes nominative Subjects and accusative Objects. Pronouns distinguish S, O, and POss(essive) forms. S is obligatorily proclitic to the verbal complex. The preverbal complex contains markers of aspect, mood, polarity, and modifiers. The object follows the verb either as an enclitic pronoun or as a free NP. ${ }^{2}$

In this paper I focus on the benefactive construction, which is unusual in allowing the beneficiary to appear in preverbal position. The following examples, both from the same text, contrast the benefactive with the possessive construction. In (I) ni sokfal 'of the owl' follows the verb with a possessive reading, and in (2) the same possessive morphology is used in preverbal position to express the beneficiary.

I. This paper has benefited substantially from discussions with Anna Margetts and from comments by an anonymous reviewer. I am grateful to the people of Erakor village, Efate, for their hospitality. In particular, I thank the late William Wayane and the late Kalsarap Namaf and their families.

2. The main data on South Efate were recorded from I 996 to 2000. They consist of about 30 hours of recordings of a variety of speakers, mainly telling stories, but also include several multiparticipant discussions and two public court hearings. Fieldwork was funded by the Department of Linguistics and Applied Linguistics, University of Melbourne, and by a postdoctoral fellowship from the Australian Research Council. Note that $\widetilde{p}$ and $\widetilde{m}$ represent the labiovelar stop and nasal, respectively. The following are not standard abbreviations of the Leipzig Glossing Rules: DPOss, direct possession; ESBJ, echo subject; PREP, preposition; PSP, prospective; R, realis; STAT, stative. Sources of examples are given as text numbers, and where possible with archived audio start and end times. 
(I) Mlapuas kin $i=$ min nalkis ni sokfal. owl sp. REL 3S.R.SBJ=drink herbs of owl sp. 'It was Mlapuas who drank Sokfal's herbs.'

(24:I4) (005Ax, I649.7I99, I668.000I)

(2) $\mathrm{Ki}=\mathrm{ni}$ sokfal ut nai. 3S.IRR.SBJ=of owl sp. pour water 'He poured water for Sokfal.' (lit. he, for the owl, poured water) (24: I0) (O05Ax, I 59I.62, I 594.740I)

As we will see in the following section, it is not unusual in Oceanic languages for the benefactive to be expressed with possessive morphology. In the literature on benefactives it is less common to find a construction grammaticalized to the extent that we do in South Efate. To show that the benefactive occurs in a unique position I will contrast it with the ditransitive construction (3.I) and with the possessive construction (3.2), with which the benefactive shares morphological marking. I will then show that the presence of a preverbal benefactive is an areal feature shared with languages to the north of South Efate.

2. THE BENEFACTIVE IN OCEANIC LANGUAGES. In an overview of benefactive marking in Oceanic languages, Song (I998) observes that benefactive constructions in some Oceanic languages have arisen from possessive classifiers, with the possessor being reinterpreted as the beneficiary. Margetts (I999:327) discusses the benefactive in Saliba, and points out the expected relationship between a possessive and benefactive reading, such that typically "if the beneficiary is not the possessor of the object prior to the expressed action it will be the possessor after the action is completed." One of the strategies used to distinguish possessive from benefactive constructions is a change in word order (Song I998:265). Margetts (2004) suggests three stages in the shift from Oceanic possessive to benefactive marking, beginning with (I) attributive possession with benefactive implicature; (2) separate constructions with distributional overlap; and finally (3) separate constructions without distributional overlap.

In some languages, there is ambiguity between a possessive and benefactive reading of morphologically possessive constructions, as we would expect following stages (I) and (2) above. For example, in Lewo on the island of Epi, north of Efate, Early (I994) notes that there is a benefactive use of prepositional phrases that can be determined pragmatically. However, as he notes, "in many situations, the close semantic relatedness of the directional goal and beneficiary role makes it difficult to distinguish them" (Early I994: I80).

South Efate has resolved this ambiguity by distinguishing possessive from benefactive phrases by word order (i.e., Margetts's stage three). We will see more examples below, but first I will show that the benefactive does not use the same strategies for encoding participants as do ditransitive verbs or possessive constructions.

\section{TYPICAL DITRANSITIVE AND POSSESSIVE CONSTRUCTIONS IN} SOUTH EFATE. Ditransitive verbs in South Efate take two objects that both follow the verb, unlike the beneficiary, which precedes the verb. Furthermore, while the pos- 
sessive and benefactive are morphologically identical, they occupy mutually exclusive sentential positions.

3.1 DITRANSITIVES IN SOUTH EFATE. The recipient of the most typical ditransitive verb $t u$ 'to give' can be expressed either by a suffix on the verb stem, or by an NP following the stem. The indirect object (IO) appears as an NP and cannot be cross-referenced. In (3) the 2 SG recipient is expressed by a 2 S.OBJ suffix $-k$. The theme, nalkis 'grass' follows the 2SG.OBJ suffix.

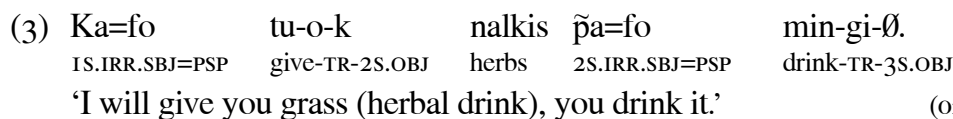

(024:7)

In (4) there are two mentions of the ditransitive verb tu 'give', and in each the object appears as a free pronoun ( $\mathrm{ag}$ '2SG' and kineu 'ISG') and the theme follows immediately after the object pronoun.

(4) $\mathrm{I}=\mathrm{tu} \quad$ ag ntaewen, $\mathrm{i}=\mathrm{tu} \quad$ kineu ntaewen. 'He gives you knowledge, he gives me knowledge.'

(o87:64) (980I7a, 2459.2800, 2470.780I)

In (5) the 3SG recipient is marked by a zero morpheme and the theme is introduced by the preposition $k i$.

(5) Go marik naot ki=preg-i- $\varnothing \quad$ Sualo i=mai go

and mister chief 3S.PRF.SBJ=make-TR-3S.OBJ S. 3S.R.SBJ=come and

$\begin{array}{lllll}\text { ki=tu-a- } \varnothing & \text { ki } & \text { tesa } & \text { nmatu nega } \\ \text { 3s.PRF.SBJ=give-TR-3s.oBJ } & \text { PREP } & \text { child } & \text { female } & \text { 3s.POss } \\ \text { nig nmatu } & \text { nega } & \text { iskei. } \\ \text { of wife } & \text { 3s.POss } & \text { one }\end{array}$

'And the chief made Sualo approach and he gave him a daughter from one of his wives.'

(053:I7)

The above examples show that there is no slot preceding the verb and following the subject proclitic that is available to any of the objects $(\mathrm{O} / \mathrm{IO})$ in a ditransitive construction. This is the position in which the benefactive construction occurs.

3.2 POSSESSIVE FORMS. As is common in Oceanic languages, there are two possessive constructions in South Efate: the direct possessive construction, in which a suffix attaches directly to the possessed noun (typically a relationship or part/whole term), and the indirect possessive. South Efate has no special possessive forms for consumable items, as are found, for example, in Paamese (Crowley I982:2 IO-I2). For the purposes of this paper I discuss only indirect possession, as it is the construction employed in encoding the benefactive.

Indirect possession is expressed by a (possessed) NP followed by a prepositional phrase encoding the possessor. The prepositional phrase can consist of either a possessive pronoun (6a), or a preposition and NP (6b). A small group of relationship terms 
allow possession to be encoded paratactically (6c), where a possessor nominal follows the nominal encoding the possessed. ${ }^{3}$ These are all represented schematically in (6), and examples of each follow.

(6)

$\begin{array}{ll}\quad \text { POSSESSED } & \text { POSSESSOR } \\ \text { a. NP } & \text { possessive pronoun } \\ \text { b. NP } & \text { prepositional phrase introduced by } n i / n i g \\ \text { c. } \text { NP } & \text { NP }\end{array}$

a. The possessed nominal followed by a pronominal possessor is illustrated in (7), in which neu 'IS.POSs' is the possessor of the preceding noun phrase nawesien pei 'first job'.

(7) Nawesien pei neu, a=weswes Hotel Lagon. job first Is.POss Is.R.SBJ=work H. L.

'My first job, I worked at the Hotel Lagon.'

(980I2 WT)

b. In (8) the possessor, Efat 'Efate', follows the preposition $n i$ and the possessed

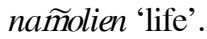

(8) Nam̃olien ni Efat mes na-sertep̃al-wen i=top.

life of Efate today the-nonbelief-NML.SBJ 3S.R.SBJ=high

POSSESSED [PREP PHRASE]

'Efate's life today, lack of faith is too great.'

(980Iob, I598.8799, I609.9I99)

In (9) we see the prepositional phrase 'of his father', which itself includes the possessed form apap nega 'his father', each possessed item being followed by the possessor.

(9) Me i=tap metpakor nafsan nig apap nega mau. but 3S.R.SBJ=not forget story of father 3S.POSS NEG2 POSSESSED [PREP PHRASE]

'But he didn't forget his father's story.'

c. In (IO), rait 'mother' is possessed by the following nominal tmak 'my father' in a paratactic construction.

(Io) Rait tm-ak i=pi natam̃ol ni Australia. mother father-IS.DPOss 3S.RSBJ=be person of A.

'My father's mother was an Australian.'

(GZ 98004)

Only forms $a$. and b. above are relevant to this discussion, as the benefactive construction employs possessive morphology and not the paratactic possessive illustrated in (IO). In all of these possessive constructions the word order is strictly possessed/possessor, unlike the benefactive construction, in which possessive prepositional phrases occur with no possessed NP.

3. Possessive pronouns can occur without a possessed noun, but in this case they are nominalized with the determiner $t e-$, as in the following example:

$\begin{array}{llll}\text { Nagi pei ga } \quad \mathrm{i}=\mathrm{ta} & \text { pi te-gar } & \text { mau. } \\ \text { name first } 3 \mathrm{~S} \quad \text { 3S.RSBJ=not } & \text { be } & \text { DET-3P.POSS } & \text { NEG2 } \\ \text { 'His first name was not theirs.' } & & \end{array}$ 
4. THE BENEFACTIVE CONSTRUCTION IN SOUTH EFATE. In this section I contrast examples of the benefactive construction with the ditransitive and possessive constructions outlined in section 3. As we have already seen, the benefactive construction employs a prepositional phrase in preverbal position, preceded by the preverbal complex that would otherwise directly precede the verb. The $\mathrm{S}$ proclitic and $\mathrm{V}$ are the only obligatory elements of the verbal complex (see [ I I]), but if any preverbal material is present, then it will host the $\mathrm{S}$ proclitic, as we see in (I2).

( I I) $\mathrm{S}=(\mathrm{PVC})$ (Benefactive Phrase) $\mathrm{V}$

In the first clause of (I2) the subject $r u=$ '3P.R.SBJ' is proclitic to the 3 SG benefactive $n e g a$, and in the second clause the same benefactive form, together with its referent (Captain Pierre), occurs between the subject proclitic $i=$ '3S.R.SBJ' and the verb slat 'take'.

(I2) $\mathrm{Ru}=$ nega nep ki tete mane me Apu Tata $\mathrm{i}=\mathrm{po}$

$\begin{array}{lllll}\text { 3P.R.SBJ=3S.BEN } & \text { throw TR some money } & \text { but A. T. } & \text { 3S.R.SBJ=PSP } \\ \text { nega Captain Pierre slat-i- } \varnothing & \text { pan. } & \\ \text { 3S.BEN } & \text { C. } & \text { P. } \quad \text { carry-TR-3S.OBJ } & \text { go }\end{array}$

'They threw in money for him, and Apu Tata took it for Captain Pierre.'

(053:65)

In (I3), the subject clitic $k a=$ 'IS.IRR.SBJ', which is ordinarily proclitic to the verbal complex, is proclitic to the pronoun gag '2S.BEN' (as there are no morphemes of the preverbal complex present to which it would otherwise attach).
(I3) $\widetilde{\mathrm{Pa}}=\mathrm{til}-\mathrm{i}-\varnothing$
na " $\mathrm{Ka}=\mathrm{gag}$
2S.IRR.SBJ=tell-TR-3S.OBJ
say IS.IRR.SBJ=2S.BEN
traus kastom."
'You say, "I'll talk to you about custom.",
tell custom

(83:32: 980I0a, 2 I64.5599, 2 I 74.5200)

While possessive and benefactive morphology are identical, there is no possession entailed in a benefactive construction, nor is there a possessed item expressed. Example (I4a) shows the pronominal possessor $g a$ '3s.Poss' following the noun nafu $\widetilde{m k a s}$ 'flowers' in canonical possessive construction word order, as discussed in 3.2 above. Contrast (I4a) with (I4b) in which the same pronoun $\mathrm{ga}^{\text {' }} 3 \mathrm{SS}$.BEN' in preverbal position encodes the beneficiary of the flowers being brought.
(I4)
a. $U=$ sat nafü̃mas ga mai.
IP.EXCL.R.SBJ=take flower 3S.Poss hither
'We brought his flowers.'
b. $U=$ ga sat nafumkas mai.
IP.EXCL.R.SBJ=3S.BEN take flower hither
'We brought flowers for him.'

(elicited)

(98005)

In ( I 5a) the food is marked as being possessed because it is followed by the 3s.POss pronoun $g a$. In $(\mathrm{I} 5 \mathrm{~b})$ the same pronoun occurs in preverbal position and encodes the beneficiary. 


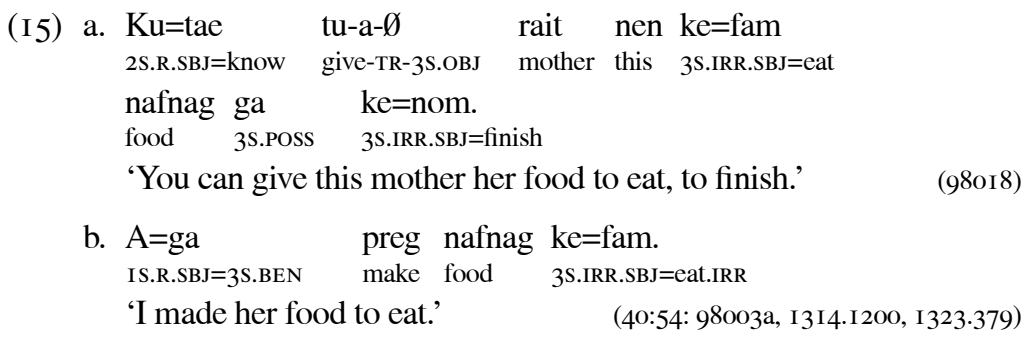

These examples show the difference between the possessive phrase preposed to the verb encoding the benefactive and the position encoding possession following the possessed noun.

Examples ( $\mathrm{I} 6 \mathrm{a}$ ) and ( $\mathrm{I} 6 \mathrm{~b}$ ) contrast the possessive and benefactive and distinguish between building a house for someone and doing it for their benefit. The relationship between a future possessor (someone for whom the house is being built) (I6a) and a beneficiary (someone for whose benefit the house is being built, but who may not be the owner) ( $\mathrm{I} 6 \mathrm{~b}$ ) has been noted by Margetts (2004) as being the path by which a separate benefactive construction can arise.
a. I=to tfag nasum ni apu.
3S.R.SBJ=STAT build house for grandfather

'He is building grandfather's house.'

(elicited)
b. I=to ni apu tfag nasum.
3S.R.SBJ=STAT of grandfather build house

'He is building a house for grandfather (for his benefit).' (elicited)

The following example is part of a story told about a spirit who will do the bidding of the speaker by punishing someone on the speaker's behalf. The speaker says to the spirit, "You will hit him for me." What this and previous examples of the preposed possessive phrase have in common is a sense of an action occurring for someone's benefit (morphologically marked as being the possessor).

$$
\begin{aligned}
& \text { (I7) } \widetilde{P} a=f o \text { neu wat-gi- } \varnothing \text {. } \\
& \text { 2S.IRR.SBJ=PSP.IRR IS.POSS hit-TR-3S.OBJ }
\end{aligned}
$$

(077:I3) (98009bx, I057.6, I059.36I I)

A possessed object and benefactive phrase do not compete for the same slot, as shown by their expression by the same possessive pronominal in example (I8). The two constructions can cooccur, which provides evidence of the grammaticalized status of the benefactive construction.

$$
\begin{aligned}
& \text { (I8) } \mathrm{Ru}=\text { gamus preg na naftourwen gamus. } \\
& \text { 3P.SBJ=2D.OBJ make DET wedding 2D.OBJ } \\
& \text { 'They will make your wedding for you.' }
\end{aligned}
$$

In (I9) the $\mathrm{O}$ is possessed ('your life'), while a benefactive phrase occurs in the preverbal slot, again showing the complementary distribution of the possessive and benefactive constructions. 
(I9) $\mathrm{Me} \mathrm{ku=ga} \mathrm{traus} \mathrm{nam̃olien} \mathrm{gag.}$ and 2S.R.SBJ=3S.BEN tell life 2S.POSS

'And you tell him about your life.'

(lit. you tell for him the story of your life)

(8I:24) (980I0a, I084.3, I090.3400)

Possessed beneficiaries are encoded just as any complex phrase in the benefactive position. In (20) we see 'for his son' as a benefactive phrase that includes a possessed nominal (the chief's brother's son), distinguishing possession from benefaction.
(20) $\mathrm{I}=\mathrm{pi} \quad$ esuan npalu-n $\quad \mathrm{i}=$ tae $\quad$ nig tesa nanwei nega 3S.R.SBJ=be where brother-3s.DPOSS 3S.R.SBJ=know of child man 3s.POss
slat nafinaotan.
take chiefly.line
[BEN[POSS ]]

'That is where the chief's brother can take the chiefly line for his son.'

The previous examples show that the benefactive phrase can be fairly complex, but the extent of that complexity is shown in (2I), where it consists of a relative clause dependent on a possessive NP, all occurring within the slot between the possessive preposition nig (signaling the beginning of the benefactive clause) and the main verb slat.

(2 I) I=nig tesa taklep nanwei nig marik pal-un nag i=pi 3S.R.SBJ=of child firstborn male of mister brother-3S.DPOSS REL 3S.R.SBJ=be [BEN [POSS [REL

naot pur marik N. K. slat-ki nafinaotan.

chief big mister N. K. take-TR chiefly.line

]]]

'He, for the firstborn son of his brother who was the big chief NK, took the chiefly line.'

(53:46)

We can further distinguish the possessive from the benefactive construction by showing that benefactives can occur with intransitive verbs, in a construction in which possession is not a possible reading, as in (22), where the intransitive verb traus 'to tell' has no object, but does have a beneficiary, neu 'ISG'.

(22) Kat natrauswen ga nrak lap i=to neu traus. because story 3S.POSS time many 3S.R.SBJ=STAT IS.BEN tell

'Because he told his story to me many times.' (lit. because, his story, many times he would to me tell)

(OI5:31)

(23) $\mathrm{Ruk}=$ fo nig nam̃er nfanu wan weswes.

3P.IRR.SBJ=PSP.IRR of people land this work

'They will work for the people of the land.'

(adapted from Anon I874; Genesis I5:I3)

None of the examples of the benefactive includes a malefactive sense. Attempts to elicit the following malefactive sense with a benefactive construction failed. The speaker said that by putting the possessive form in preverbal position it implied that 
"something nice" was happening to the addressee. Using the benefactive construction made the proposition a humorous threat ("I will break your head for you").

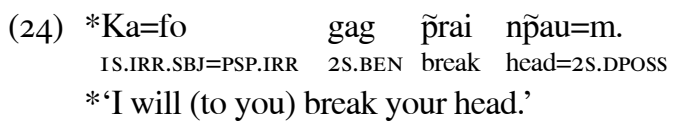

(elicited)

To seriously threaten someone with a broken head one would say (25) using the direct possessive in this case.

(25) $\mathrm{Ka}=$ fo $\quad$ prai $n \tilde{p a u}=\mathrm{m}$.

Is.IR.SBJ=PSP.IRR break head=2S.DPOSS

'I will break your head.'

(elicited)

Because the benefactive NP occupies a slot outside of those filled by the object and indirect object, it is possible to encode four participants (three arguments and the beneficiary) with the ditransitive verb $t u$ 'give'. In (26) the speaker asks that five arrows be given on his behalf. We know that the action is on behalf of the speaker, because if he were asking for arrows for himself (e.g., 'you give me five arrows'), the suppletive verb form for 'give me' would be tao and not tua 'give him' as it is in (26).

(26) $\widetilde{\mathrm{P} a}=$ freg-si nas,

2S.IRR.SBJ=make.IRR-all bow

$\widetilde{\mathrm{p} a}=$ neu tu-a- $\varnothing \quad$ ki timen ke=lim.

2S.IRR.SBJ=IS.BEN give-TR-3S.OBJ PREP arrow 3S.IRR.SBJ=five

'You make the bow, you give him five arrows for me (on my behalf).'

(980I7b, 2586.8599, 2593.6075)

Similarly in (27) nеи 'Is.Poss' encodes the participant on whose behalf the letter is given to another person, allowing the expression of the theme ("the letter"), the recipient ("him"), and the beneficiary (nеи 'IS.POss').

$$
\begin{aligned}
& \mathrm{Ka}=\text { fo preg leta ke=skei. Ale } \mathrm{a}=\mathrm{tu} \text { nat, } \\
& \text { IS.IRR.SBJ=PSP.IRR make letter 3S.IRR.SBJ=one okay IS.R.SBJ=give man } \\
& \text { " } \widetilde{\mathrm{P}} \mathrm{a}=\text { fo neu tu-a- } \varnothing \text { ki- } \varnothing \text {." } \\
& \text { 2S.IRR.SBJ=PSP.IRR IS.BEN give-TR-3S.OBJ PREP-3S.OBJ } \\
& \text { 'I will write a letter. Then I give it to a man, "You will give it to him for }
\end{aligned}
$$

From all of these examples it is clear that there is a morphosyntactically distinct benefactive construction in South Efate that involves the beneficiary (encoded by possessive morphology) preceding the verb.

5. TYPOLOGY OF OCEANIC BENEFACTIVES. Song (I997) distinguishes three types of benefactive construction for Oceanic languages characterized as P-type (possessive classifier-based); V-type (verb-based); and N-type (noun-based). Data for North/Central Vanuatu considered by Song (I997:49) suggest that Paamese has the Vand P-types, exploiting classifiers as a base to which possessive pronominal sufixes are attached. The closest language to South Efate mentioned by Song is Nguna, which he 
notes as being of the V-type. V- type or verb-based benefactives, if they are not clearly derived from a verb meaning 'to give', retain "certain vestiges or properties of a verb, e.g., person marking" (Song I997:36). The only grammatical analysis of Nguna is a short sketch by Schütz ( I969a), which mentions a distinct construction of the kind discussed here for South Efate. Indirect possession in Nguna, as in South Efate, is marked by a possessive pronoun (28) or possessive NP (29) following the possessed noun. Examples of pronominally encoded benefactives follow (glossed by Schütz as 'intentional'), and then in example (33) we see a beneficiary encoded by a possessive phrase rather than a pronoun.
NGUNA 4
(28) na-vinaga aneana
DET-food 3s.Poss
'his food'
(Facey 1988:306)
(29) E pei varea ni Togalapa.
it be meeting.house of Togalapa
'It was Togalapa's meeting house.'
(Schütz I969a:73)
(30) Ee, tu ga mateata pauri a.
no we.INCL int(entional) 3P.BEN pile.firewood it
'No, we'll pile firewood for them.'（adapted from Schütz I969b:49)
(3I) $\mathrm{Au}$ ga wo manimu sui na-kapu kiiki.
we.EXCL int(entional) will 2P.BEN blow DET-fire small
'We'll make something for you to eat.'（adapted from Schütz I969b:45)
$\begin{array}{llll}\text { (32) } & \text { Tu } & \text { ga } & \text { maginau lalawo. } \\ \text { IP.INC.SBJ } & \text { intentional } & \text { Is.BEN } & \text { plant }\end{array}$
'Let's plant it for me.'＜noBreak>＜noBreak>（adapted from Facey I988:226)

The previous examples show a possessive pronoun encoding the benefactive role. Example (33) shows a prepositional phrase in the same position.

(33) Goo te ragi seara naka ni Farealapa eu magi naka ni then a time some people of Farealapa they for people of

Utanilagi lalawo.

Utanilagi plant

'In those days sometimes the people of Farealapa planted for the people of Utanilagi.'

(Facey I988:136)

This construction should not be called V-type, as it relies on a pronominal possessive (and also, in the case of South Efate, a possessive NP). As in South Efate, the position of the possessive correlates consistently with the semantics of either a benefactive in preverbal position, or a possessive elsewhere. Thus both the Nguna and South Efate benefactive should be classified as Song's P-type.

4. Glosses are adapted from those provided in the original sources. 
6. THE BENEFACTIVE AS AN AREAL FEATURE. A preverbal benefactive is a feature of the group of languages on Efate and immediately to its north. We have already seen examples from South Efate and Nguna ([28-33] above, including both prepositional and full NP benefactive phrases). In Namakir (Sperlich I99I:27I), spoken on Makira Island, located between Epi and Efate, there is a benefactive construction that occupies the same preverbal position as in South Efate, but it is apparently limited to pronominal expression of the beneficiary, with pronominals formed with the possessive min 'for'.

(34) Ni min-io da? na-masimas.

Is for-me cut ART-knife

'I (for myself) cut a knife.'

(slightly adapted from Sperlich I99I:I49)

(35) Ke-Jack no min-ini i-boh na-im. Art-Jack PROG for-3s 3s-build ART-house

'Jack is building a house for her.' (slightly adapted from Sperlich 1991:27I)

Similarly, the language of Lelepa Island, to the northwest of Efate, displays at least a pronominal preverbal benefactive, as shown in (36)

(36) $\mathrm{Ku} \underset{\text { 2S.R.SBJ }}{\mathrm{ga}}$ 3S.BEN take

'You take it for him.'

(from fieldnotes)

The preverbal pronominal position is recorded in Macdonald's 1907 dictionary, where he says, "thus instead of ka fano, kefano we have aga fano, iga fano, in exactly the same sense, but, literally, 'I to go,' 'he to go.' This variation in Ef. of the order of the three elements of the expression in no way varies the sense, and seems to be purely for euphony" (Macdonald 1907:84-85). If his conclusion about the sense of these forms is correct, it indicates that the grammaticalization of the benefactive was only incipient at the end of the nineteenth century. However, it is more likely that the benefactive was already a functioning construction that was not taken into account by Macdonald's analysis, especially considering that there are examples of benefactives in the 1874 Genesis translation, as seen in (23) above.

Capell (n.d.) noted the preverbal prepositional phrase as a feature of Nguna and associated languages: "A number of particles in Nguna-Efate occur in an unexpected position, viz, before the verb: these are a few conjunctions, and certain of the prepositional nouns. ... Two morphemes [that] function prepositionally need special treatment because they cause perturbation of the word order. These in the Nguna form are agi and magi 'for' and their peculiarity is that they intervene between tense particles and verb, whether they are completed by a suffixed pronoun or by a noun. The subject indicator and tense particle retain their normal places and the preposition is placed between them and the verbal stem. They are found in all the dialects."

Lynch (2004) has pointed out a number of linguistic features shared by South Efate and languages of southern Vanuatu. These features suggest a linkage between these languages at the level of a subgroup of Proto-Oceanic. Without detracting from this observation, the areal distribution of preverbal benefactive phrases suggests a cohesion of central Vanuatu languages, perhaps due to a shared history and diffusion, or perhaps due to shared inheritance. 
7. PATHWAYS TO THE SECOND POSITION. The grammaticalization of a benefactive from a possessive construction is widely attested in languages of the world (as discussed above, and see Song 1997 and Margetts 2004). A change of word order is a final stage in this grammaticalization, with the benefactive and possessive constructions occupying mutually exclusive positions. In South Efate the benefactive construction is the only phrasal element permitted between the preverbal complex and the verb. How did that position become available? Croft (I990:233-34) discusses "verbal attraction" as a form of morphosyntactic gramaticalization by which "various dependents on the verb — adverbs, auxiliaries, pronominal subjects and objects, etc.—move to a position next to the verb." The benefactive in South Efate has moved to a preverbal position, as an instance of "verbal attraction," but the question remains, why that particular position?

Reanalysis of verbs as directional particles may provide a bridging context in which prepositional phrases occur before items that are directional particles identical in form to the verbs from which they have derived. Thus, in the schema in (37), the directional particle, formally identical to the verb from which it is derived, occurs following the sentential complement.

(37) PVC PREP/VERB COMPLEMENT DIRECTIONAL.PARTICLE

I suggest that there are two features of this structure that provide a route for the benefactive occurring before the main verb. One is the directional particle, and the other is the verbal preposition, which I will now address in turn.

In South Efate, as in other Oceanic languages (see Lichtenberk I99I), several verbs have been reanalyzed as directional particles in post VP position and now only express direction ('to', 'at', 'along', 'from', and so on) in that position..$^{5}$ Directional particles in South Efate are homophonous with the verbs from which they are clearly derived, thus:

(38) VERB

$\begin{array}{ll}\text { mai } & \text { 'to come' } \\ \text { pan } & \text { 'to go' } \\ \text { ur } & \text { 'to follow' } \\ \text { to } & \text { 'to stay' } \\ \text { nrokot } & \text { 'to cross' }\end{array}$

\section{PARTICLE}

mai 'hither'

pan 'from'

ur 'along'

to 'at'

nrokot 'across'

It is because the relationship between a verb and derived directional particle is so transparent that the directional particle retains vestiges of its verbal status. Thus prepositional phrases occurring before the directional particle can be interpreted as occurring in the same position as the benefactive, that is, before the main verb, as we will see below.

Verbal prepositions have been noted in Oceanic languages (Durie I988, Pawley I973) as sharing features of both prepositions and verbs. Durie (I988:3), in his discussion of verbal prepositions, argues that the reanalysis of serial verbs into prepositions is due to the diachronic instability of serial verbs. Crowley (200I) similarly talks of the "dissolution" of serial verbs into other word classes, including prepositions and directional particles.

5. Lynch, Ross, and Crowley 2002:85 suggest that the development of directional particles (or enclitics) from directional verb serializations could have occurred in POc, but could also be "the outcomes of post-POc encliticization." 
Verbal prepositions like plak 'to be with/with' in South Efate can act as the main verb in a sentence, as shown in (39).

(39) Gar ru=plak pisplolo mas ko nafon ses. 3PL 3P.R.SBJ=with pubic.cover only or skirt small 'They had pubic covers only or small skirts.'

(98002a, I678.6000, I682.7858)

Typically plak occurs with a directional particle following its complement, as in (40) below, where the directional particle is mai 'hither'. Note in the following examples that plak occurs with a subject proclitic and with elements of the preverbal complex, indicating that it is functioning as a verb in these cases.

(40) Ale i=po plak Apu Kalmet mai. okay 3S.R.SBJ=PSP.R with grandfather K. hither 'Okay, he then came with Apu Kalmet.' (lit. he, with Apu K. came)

( $\mathrm{I} / \mathrm{IO} / 98)$

The following example shows nrokot 'to cross' following plak 'with' plus its pronominal object. In both (40) and (4I) the slot before the directional particle is identical to the preverbal slot in which benefactive prepositional phrases occur.

\begin{tabular}{|c|c|}
\hline & nrokot kin $\mathrm{ru}=\mathrm{pak}$ \\
\hline h-TR-3Р.OBJ & REL 3P.R.SBJ $=$ to \\
\hline
\end{tabular}

'They went with them across so they went to Erakor.'

(056:29) (98002b, 984.6, 988.0599)

(42) Go kineu kin a=po to plak America ur ser naor. and IS. REL IS.R.SBJ=PSP stay with A. follow every place

'I went with the Americans around all over the place.'

(43) $\mathrm{I}=$ mai kai skot Apu nimam to naur to.

3S.R.SBJ=come ESBJ with grandfather IP.EXCL at island at

'He came and with our grandfather stayed at the island.'

(PK 28/9/98)

In (40-43) the prepositional phrase has no benefactive reading. These examples have an ambiguous structure, where skot and plak are acting either as prepositional verbs whose objects are then followed by directional particles (to 'at', mai 'hither', ur 'follow', and so on) or they are acting as prepositions introducing a prepositional phrase, and the directional particle could then be interpreted as being the main verb. Let us take example (4I) and display this ambiguity as in (44a), where the prepositional verb plak 'to be with' and its complement (-r '3P.OBJ') precede the main verb (nrokot 'to cross'). However, we could also interpret plak as being the main verb in this sentence, as in (44b) with nrokot acting as a directional particle.

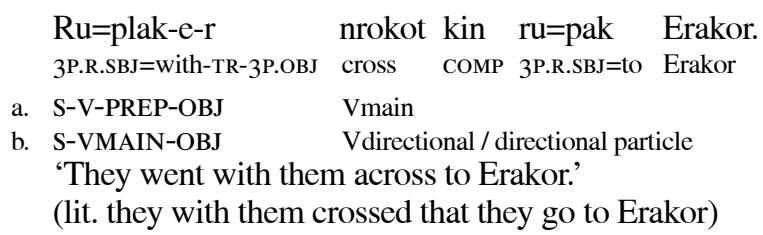


The directional particle could be interpreted as being a main verb in what could also be seen as verbless sentences, due to the homophony of directional particles and their equivalent verbs. The two lines of structural analysis in (45) show alternate analyses possible for this type of sentence, with (45a) showing the verbless sentence analysis, and (45b) showing the analysis with the directional particle as the main verb. Emar 'Mare' is a place-name that bears the locative prefix $e$ - and so is here a prepositional phrase ('at Mare').

\begin{tabular}{|c|c|c|c|c|}
\hline $\begin{array}{l}\text { Apu } \\
\text { grandfather }\end{array}$ & $\begin{array}{l}\text { nigmam } \\
\text { IP.EXCLPOSS }\end{array}$ & $\begin{array}{l}\mathrm{i}=\text { to } \\
3 \text { S.R.SBJ }=\text { STAT }\end{array}$ & $\begin{array}{l}\text { E-mar } \\
\text { Loc-Mare }\end{array}$ & $\begin{array}{l}\text { mai. } \\
\text { come }\end{array}$ \\
\hline$[\mathrm{N}$ & Spec & ] N ASPECT & N/PP & Directional Particle \\
\hline$[\mathrm{N}$ & Spec & ] N ASPECT & N/PP & $\mathrm{V}$ \\
\hline
\end{tabular}

'Our grandfather came from Mare.'

(980I4a, 8I2.3000, 8I9.I80I)

Thus there is a potentially ambiguous structure, one that allows prepositions to bring their complements into a preverbal position. Once South Efate verbal prepositions occurred in this ambiguous slot, it could have facilitated nonverbal prepositions such as those marked by the locative $e$ - or the possessive $n i$ to follow with a benefactive reading.

8. CONCLUSION. There is a benefactive construction in South Efate that employs possessive morphemes in preverbal position. While grammatical objects and their possessors follow the verb, the benefactive occurs between the preverbal complex and the verb. I suggest that this position could have arisen from the inherent structural ambiguity of prepositional verbs, thus providing a vector for true prepositions that were employed in encoding a benefactive reading. The use of a preverbal benefactive construction is restricted to a group of languages from Efate and its immediate north and suggests a commonality among them, either by diffusion or inheritance, that is not shared with languages to the south.

\section{REFERENCES}

Anon. I 874. Kenesis natus a bei nag Moses ki mtir i. Trans. J. Cosh. Sydney: British and Foreign Bible Society.

Capell, Arthur. n.d. Perturbation of word order. Ms. http://paradisec.org.au/fieldnotes/ AC2/VNEFAT.htm\#VNEFATI4

Clark, Ross. 1985. The Efate dialects. Te Reo 28:3-35.

Croft, William. I990. Typology and universals. Cambridge: Cambridge University Press.

Crowley, Terry. I982. The Paamese language of Vanuatu. Series B-87. Canberra: Pacific Linguistics.

- I998. An Erromangan (Sye) grammar. Honolulu: University of Hawai 'i Press. . 200I. Serial verb constructions in Oceanic languages. Lecture notes.

Durie, Mark. I988. Verb serialization and "verbal prepositions" in Oceanic languages. Oceanic Linguistics 23: I-23.

Early, Robert. I994. A grammar of Lewo, Vanuatu. PhD thesis, RSPAS, Australia National University. 
Facey, Ellen 1988. Nguna voices: Text and culture from central Vanuatu. Calgary: University of Calgary Press.

Lichtenberk, Frantisek. I99I. Semantic change and heterosemy in grammaticalization. Language 67:475-509.

Lynch, John. 2004. The Efate-Erromango problem in Vanuatu subgrouping. Oceanic Linguistics 43:3 I I-38.

Lynch, John, Malcolm Ross, and Terry Crowley. 2002. The Oceanic languages. Surrey, England: Curzon Press.

Macdonald, Donald D. I907. The Oceanic languages: Their grammatical structure, vocabulary, and origin. Oxford: Henry Frowde.

Margetts, Anna. I999. Valence and transitivity in Saliba, an Oceanic language of Papua New Guinea. MPI Series in Psycholinguistics I2. Munich: Max-Planck-Gesellschaft zur Förderung der Wissenschaften.

- 2004. From implicature to construction: Grammaticalization from possession to benefaction in Oceanic languages. Oceanic Linguistics 43:445-69.

Pawley, Andrew. 1973. Some problems in Proto-Oceanic grammar. Oceanic Linguistics I2: I03-88.

Schütz, Albert J. I969a. Nguna grammar. Oceanic Linguistics Special Publication No. 3. Honolulu: University of Hawai'i Press.

- I969b. Nguna texts. Oceanic Linguistics Special Publication No. 4. Honolulu: University of Hawai'i Press.

Song, Jae Jung. I997. The history of Micronesian possessive classifiers and benefactive marking in Oceanic languages. Oceanic Linguistics 36:29-64.

- I998. Benefactive marking in Oceanic languages: From possessive classifiers to benefactive markers. In Case, typology and grammar, ed. by Anna Siewierska and Jae Jung Song, 247-75. Amsterdam: John Benjamins.

Sperlich, Wolfgang. I99I. Namakir: A description of a Central Vanuatu language. $\mathrm{PhD}$ thesis, University of Auckland.

Thieberger, Nicholas. 2004. Topics in the grammar and documentation of South Efate, an Oceanic language of Central Vanuatu. PhD diss., University of Melbourne.

Department of Linguistics and Applied Linguistics

University of Melbourne

Melbourne 30Io, AUSTRALIA

thien@unimelb.edu.au 


\section{University Library}

\section{- M M I E E R VA A gateway to Melbourne's research publications}

Minerva Access is the Institutional Repository of The University of Melbourne

Author/s:

Thieberger, N

Title:

The benefactive construction in South Efate

Date:

2006-12-01

Citation:

Thieberger, N. (2006). The benefactive construction in South Efate. OCEANIC LINGUISTICS, 45 (2), pp.297-310. https://doi.org/10.1353/ol.2007.0010.

Persistent Link:

http://hdl.handle.net/11343/31254 